\title{
New data on lichens from Salair province in Altaisky krai (Siberia, Russia)
}

\author{
E. A. Davydov ${ }^{1}$, L. A. Konoreva ${ }^{2}$ \\ ${ }^{1}$ Altai State University, Lenina str., 61, Barnaul, 656049, Russia; Tigirek State Reserve, Nikitina Str. 111, \\ Barnaul, 656043, Russia.E-mail: eadavydov@yandex.ru. \\ ${ }^{2}$ Polar-Alpine Botanical Garden-Institute, Kola Science Center, Russian Academy of Sciences, Apatity, Russia; \\ V. L. Komarov Botanical Institute, Russian Academy of Sciences, Professora Popova str., 2, St. Petersburg, 197376, Russia.
}

Key words: Asia, biodiversity, lichenized Ascomycota, new records, Salair Ridge, Zalesovsky Reserve.

Summary. In terms of lichens, Salair region is the least studied area of Altaisky krai, with as few as five species being reported from the territory, whereas Salair Range within Novosibirsk and Kemerovo regions was well investigated lichenologically. The first data on lichens of Salair province in Altaisky krai are presented: ninety six mostly corticolous and lignicolous lichen species and two non-lichenized fungi traditionally treated with lichens (Phaeocalicium polyporaeum и Schizoxylon albescens) are recorded from Abies sibirica - Populus tremula tall grass forests of Zalesovsky Reserve. Among them, Acrocordia cavata and Phaeocalicium polyporaeum are new records for Siberia. Fuscidea pusilla and Bacidina delicata are new for South and West Siberia respectively. Eighteen species are new for Altaisky krai: Absconditella delutula, Arthonia apatetica, Bacidia circumspecta, B. igniarii, B. incompta, B. polychroa, B. subincompta, Biatora efflorescens, Calicium denigratum, Melanelixia fuliginosa ssp. glabratula, Micarea lignaria, Mycobilimbia epixanthoides, Pertusaria hemisphaerica, P. leioplaca, Placynthiella dasaea, Pseudoschismatomma rufescens, Rinodina efflorescens, and Xanthomendoza fulva. Most recorded species are epiphytes, because the ground is almost completely covered by vegetation dominated by tall grasses and forbs; stones were not found. "Calicioid lichens" - three Calicium and four Chaenotheca species, which are well-known as markers of ecological continuity in forest communities, are relatively diverse and abundant. Several other species, e. g. Absconditella delutula, Acrocordia cavata, Arthonia apatetica, Bacidia spp., Collema furfuraceum, Lobaria pulmonaria, Ramalina spp. are also characteristic for old-growth biologically valuable forests in Altaisky krai. One species - Lobaria pulmonaria - is included in the Red Data Book of Russia, and another species - Ramalina roesleriin the Red Data Book of Altaisky krai. It is strongly recommended to maintain the special protection regime and exclude felling of the forest in Zalesovsky reserve.

\section{Новые данные о лишайниках Салаирского ботанико-географического района в Алтайском крае}

\author{
Е. А. Давыдов ${ }^{1}$, Л. А. Конорева ${ }^{2}$ \\ ${ }^{1}$ Алтайский государственный университет, пр. Ленина, 61, Барнаул, 656049, Россия; Тигирекский государственный \\ заповедник, ул. Никитина, 111, Барнаул, 656043, Россия. \\ ${ }^{2}$ Полярно-Альпийский ботанический сад-институт Кольского научного иентра РАН, Апатиты, Россия; \\ Ботанический институт им. В. Л. Комарова РАН, ул. Проф. Попова, 2, Санкт-Петербург, 197376, Россия.
}

Ключевые слова: Азия, биоразнообразие, Залесовский заказник, лихенизированные аскомицеты, Салаирский кряж, флористические находки.

Аннотация. Представлены данные о лишайниках ботанико-географического района Салаир и Предсалаирье в Алтайском крае. Для этой, наименее изученной с лихенологической точки зрения части края, по лите- 
ратурным данным было известно 4 вида лишайников и один вид не лихенизированного гриба - Schizoxylon albescens, в то время как в пределах Новосибирской и Кемеровской областей Салаирский кряж лихенологически изучен хорошо. Исследование проводилось в высокотравной черневой тайге Залесовского заказника, где зафиксировано обитание 96 видов, в основном, эпифитных лишайников и двух филогенетически родственных нелихенизированных грибов, традиционно рассматриваемых наряду с лишайниками (Phaeocalicium polyporaeum и Schizoxylon albescens). Acrocordia cavata и Phaeocalicium polyporaeum - виды новые для Сибири, Fuscidea pusilla - для Западной Сибири, Bacidina delicata - для Южной Сибири. Восемнадцать видов - Absconditella delutula, Arthonia apatetica, Bacidia circumspecta, B. igniarii, B. incompta, B. polychroa, B. subincompta, Biatora efflorescens, Calicium denigratum, Melanelixia fuliginosa ssp. glabratula, Micarea lignaria, Mycobilimbia epixanthoides, Pertusaria hemisphaerica, P. leioplaca, Placynthiella dasaea, Pseudoschismatomma rufescens, Rinodina efflorescens, Xanthomendoza fulva - приводятся впервые для Алтайского края. Большинство выявленных видов эпифиты, поскольку почва почти полностью покрыта высокотравьем, а каменистый субстрат не обнаружен. «Калициоидные» лишайники - три вида рода Calicium и четыре вида рода Chaenotheca, хорошо известные как маркеры экологически непрерывных (старовозрастных) лесов, довольно разнообразны и обильны. Некоторые другие виды, например, Absconditella delutula, Acrocordia cavata, Arthonia apatetica, Bacidia spp., Collema furfuraceum, Lobaria pulmonaria, Ramalina spp., также характеризуют старовозрастные биологически ценные леса в Алтайском крае. Один вид (Lobaria pulmonaria) включен в Красную книгу России, еще один (Ramalina roesleri) - в Красную книгу Алтайского края. Настоятельно рекомендуется сохранить статус особой охраны в Залесовском заказнике, исключающий рубки леса.

\section{Introduction}

Altaisky krai (Altai Territory) is a large $(169,100$ $\mathrm{km}^{2}$ ) administrative area within the Russian Federation, located at the southern part of West Siberia, between $50^{\circ}$ and $55^{\circ} \mathrm{N}$ and $77^{\circ}$ and $87^{\circ} \mathrm{E}$. The area is situated in the place of a contact of the southeastern part of the West-Siberian Plain and the Altai Mountains. It lies between 79 and 2490 $\mathrm{m}$ above sea level. A wide range of vegetation types such as semideserts, steppes, forest-steppes, taiga and high mountain types of vegetation are represented in Altaisky krai. More than $60 \%$ of plains are ploughed up by agrocommunities.

Altaisky krai is divided into 8 biogeographical regions (Silantieva, 2006), 7 of which (all apart from the $\mathrm{Ob}$ ' bottomland) were accepted by us (Davydov, 2014; see Fig. 1). One of them, Salair region, is situated in the North of Altaisky krai. Salair Ridge is an eroded plateau-type highland ca. $300 \mathrm{~km}$ in length and $15-40 \mathrm{~km}$ wide. It is a natural continuation of Altai Mountains separating the Kuznetsk Depression from the Ob' River Plain. The native vegetation of Salair Ridge is Abies sibirica tall grass forests. Nowadays the territory is mostly covered by the secondary Betula pendula or Populus tremula forests.

The first checklist of lichens, lichenicolous and allied fungi of Altaisky krai and detailed history of investigations of lichens in the area were published recently (Davydov, 2014; Davydov, Skachko, 2014). The eight regions of Altaisky krai have received varied attention from lichenologists. The best-studied region is the North-West Altai with 517 recorded lichen species known from the area (see
Davydov, 2001, 2004, 2014; Davydov et al., 2007, 2012; Davydov, Printzen, 2012a, b). In contrast, Salair region is the least studied area, with only five species reported from the territory (Davydov, 1999, 2004; Stas', 1999; Konoreva et al., 2016; Vondrák et al., 2016). At the same time, lichen biota of Salair Range within Novosibirsk and Kemerovo Regions was exstensively investigated (Sedelnikova, 2007; Baumgartner, 2012).

In spite of the fact that lichen biota of some regions is poorly investigated, it is clear that South Siberia is a major center of lichen diversity in North Asia. The main goal of the study is to contribute to the knowledge of lichen diversity in Salair region within Altaisky krai. The study is based on collections made by the authors in Zalesovsky reserve in 2012 and 2014. The list of taxa includes 98 corticolous and lignicolous species. All reported species are new to the area, except for Gyalolechia ussuriensis, Lobaria pulmonaria, and Mycobilimbia carneoalbida. Among the newly reported species, four are new either to the whole Siberia or to its major geographical subdivisions (Acrocordia cavata, Bacidina delicata, Fuscidea pusilla, and Phaeocalicium polyporaeum), and 18 species new for Altaisky krai (Absconditella delutula, Arthonia apatetica, Bacidia circumspecta, B. igniarii, $B$. incompta, $B$. polychroa, B. subincompta, Biatora efflorescens, Calicium denigratum, Melanelixia fuliginosa ssp. glabratula, Micarea lignaria, Mycobilimbia epixanthoides, Pertusariahemisphaerica, P. leioplaca, Placynthiella dasaea, Pseudoschismatomma rufescens, Rinodina efflorescens, and Xanthomendoza fulva). 


\section{Material and methods}

Zalesovsky reserve (zakaznik) is situated in the north-eastern part of Altaisky krai in the forest zone of Salair Ridge within the Berd' River basin. The regional climate is strongly continental with a mean annual temperature of $+1.7^{\circ} \mathrm{C}$. The minimum temperature is $-50{ }^{\circ} \mathrm{C}$, maximum temperature +37 ${ }^{\circ} \mathrm{C}$, mean temperature of the coldest month (January) ca $-17^{\circ} \mathrm{C}$, and that of the warmest month (July) ca $+18{ }^{\circ} \mathrm{C}$. The terrain is gently rugged, eroded, with flat and convex watershed areas dissected by a dense network of valleys and small ravines descending down to a depth of 100-200 m. The territory lies 400-600 m above sea level. The main vegetation type is subnemoral Abies sibirica-Populus tremula forests. The undergrowth is represented by Sorbus sibirica and Padus avium, the shrub layer by Crataegus sanguinea, Viburnum opulus, Ribes spicata, and Rubus idaeus (Fig. 2). The herbaceous layer is well developed consisting of ferns and tall grasses, including Dactylis glomerata and Festuca gigantea, and the forbs Aconitum septentrionale,
Angelica decurrens, and Paeonia anomala (Shmakov et al., 2009). Zalesovsky reserve includes relatively small and highly fragmented territories, covering in total about $40-50 \mathrm{~km}^{2}$ within the Salair province. Old-growth forests, which have never been cut down, have survived only within the territory of the reserve. These habitats were the focus of the present investigation.

Herbarium specimens were collected by the authors during 2012 and 2014 from the following collecting sites (WGS 84 system was used for geographical GPS coordinates):

1. "Russia, Altaisky krai, Zalesovsky district, Salair Ridge, $20 \mathrm{~km}$ NE from the Kordon settlement, headwaters of the Berd' River, alt. $430 \mathrm{~m}$. N54.4167\%, E $85.1167^{\circ}$, Abies sibirica-Populus tremula tall grass forest, 29 V 2012, leg. E. A. Davydov, and 12 V 2014, leg. E. A. Davydov, L. A. Konoreva".

2. "Russia, Altaisky krai, Zalesovsky district, Salair Ridge, $30 \mathrm{~km}$ NNE from the Kordon settlement, headwaters of the Pavlovka River (Berd' River's basin), alt. $380 \mathrm{~m}, \mathrm{~N} 54.4167^{\circ}$, E $85.1500^{\circ}$,

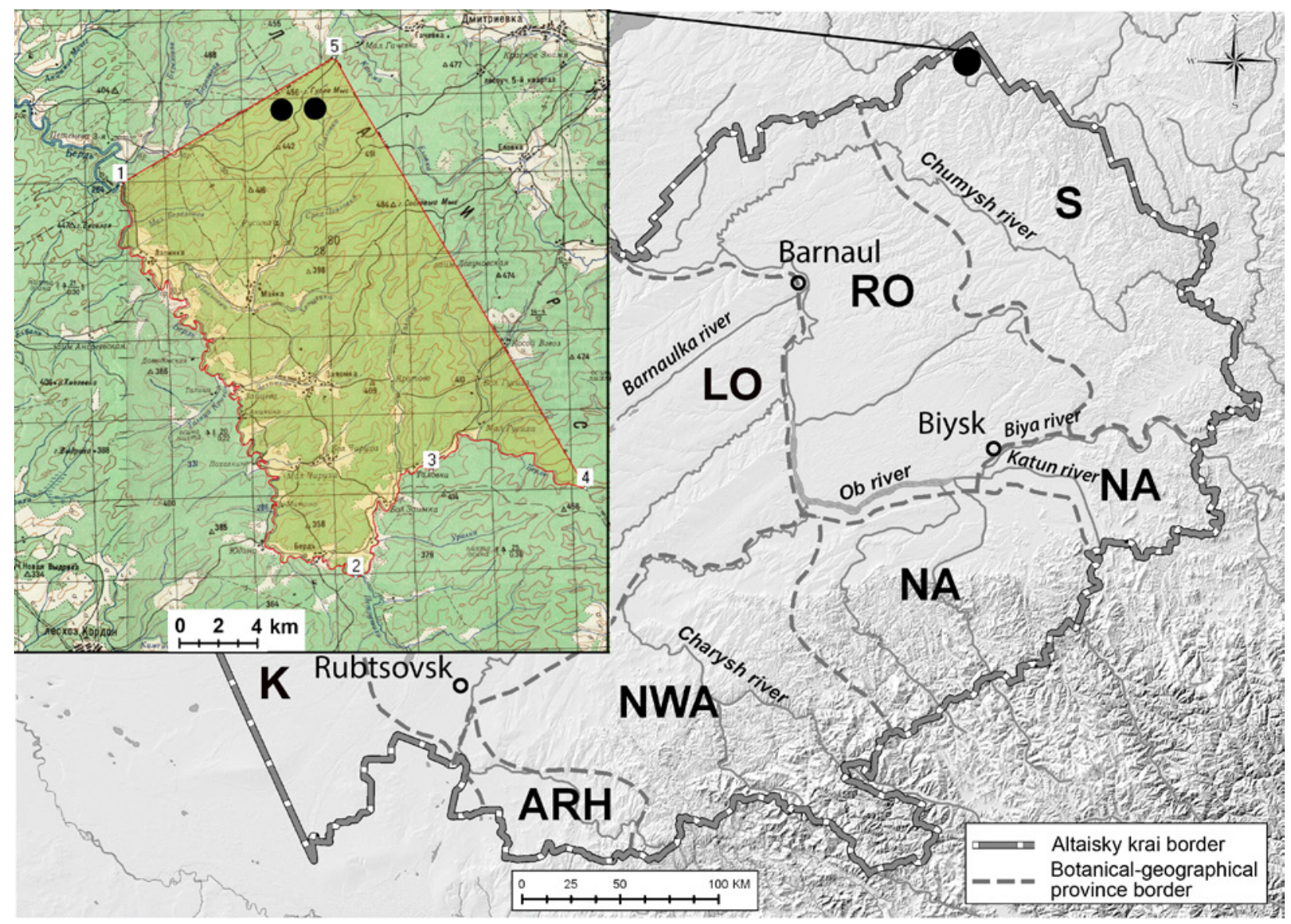

Fig. 1. Biogeographical regions in Altaisky krai (according to Silantieva, 2006, modified). K - Kulunda; LO - Ob' River Left-bank territory; RO - Ob' River Right-bank territory; S - Salair and adjacent territories; ARH - Alei River hills; NA - North Altai; NWA - North West Altai. Collecting area is marked with black circle (•). The large-scale map of Zalesovsky reserve is inserted. 
Abies sibirica-Populus tremula tall grass forest, 30 V 2012, leg. E. A. Davydov, and 12 V 2014, leg. E. A. Davydov, L. A. Konoreva".

Samples were collected from the bark of living trees and from dead wood: standing dead trees (snags), fallen logs, branches and stumps. Voucher specimens are deposited in ALTB. Morphological and anatomical characters were analyzed by applying standard methods of light microscopy. Chemical analyses of secondary products were made using standard thin-layer chromatography (TLC) techniques (Culberson, Kristinsson, 1970). Species reported for the first time for Siberia or its major geographical subdivisions are marked with (!!) and for Altaisky krai with (!). Non-lichenized fungi traditionally treated with lichens are marked $(+)$ (this only applies to Phaeocalicium polyporaeum).

The Russian distribution and/or short taxonomic notes are provided only for rare or otherwise interesting species.

\section{Results and discussion}

The list includes 98 species collected from the relatively small area which belongs to the Zalesovsky Reserve. Most species are epiphytes, because the ground is almost completely covered by vegetation dominated by tall grasses and forbs; stones were not found. "Calicioid lichens" - three Calicium and four Chaenotheca species, which are wellknown markers of ecological continuity in forest communities, are relatively diverse and abundant. Several other species, e. g. Absconditella delutula, Acrocordia cavata, Arthonia apatetica, Bacidia spp., Collema furfuraceum, Lobaria pulmonaria, Ramalina spp. are also characteristic for old-growth biologically valuable forests in Altaisky krai. One species - Lobaria pulmonaria - is included in the Red Data Book of Russia (Istomina, 2008), and another species - Ramalina roesleri - in the Red Data Book of Altaisky krai (Davydov, 2016). It is strongly recommended to maintain its special protection and exclude felling of the forest in the Zalesovsky reserve.

\section{List of species}

!Absconditella delutula (Nyl.) Coppins et $\mathrm{H}$. Kilias - on bark of Abies sibirica; collecting site: 1, coll. Davydov 10599, Konoreva.

RUSSIAN DISTRIBUTION. Scattered throughout cool temperate regions: North Ural (Hermansson et al., 2006), Russian Plain (Notov et al., 2011; Zhdanov, Volosnova, 2012), Kola Peninsula (Melekhin, 2013), and Leningrad Region (Himelbrant et al., 2015). Additionally, Sedelnikova (2013) listed this species

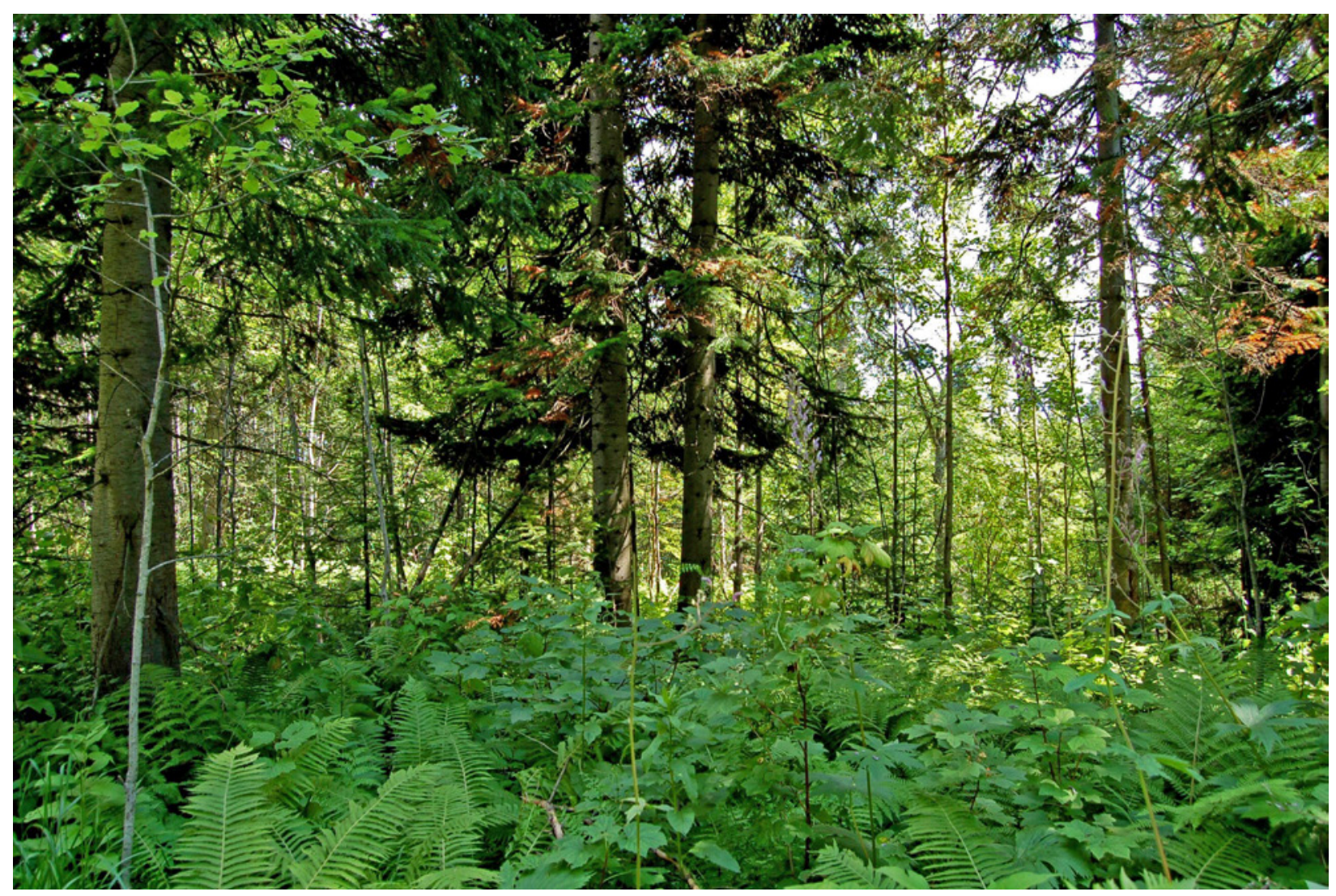

Fig. 2. Abies sibirica dominanted subnemoral tall grass forest in Zalesovsky reserve. 
for Siberia without providing precise locality details or reference to herbarium samples.

NotE: This rare and very inconspicuous species can grow on rotten wood, bark and soil. The thallus forms a glossy, greenish film on the substratum. This species is closely related to Absconditella lignicola and differs by its 3 -septate ascospores and slightly larger apothecia.

Additional material examined: RUSSIA. Belgorod region, Gubkinsky district, Dolgoe reserve, oak and pine forests, on rotten wood, 2002, Konoreva s. n. (KPABG).

!!Acrocordia cavata (Ach.) R. C. Harris - on bark of Populus tremula; collecting sites: 1, coll. Davydov 10504, 10808, 10184, Davydov 10523, Konoreva.

Russian Distribution: North-West Caucasus (Otte, 2005), North-Western European Russia (Stepanchikova et al., 2009; Notov et al., 2011; Tagirdzhanova et al., 2014).

This is a first record for Siberia and a second record for Asia outside the Caucasus.

NotE: This rare pyrenolichen is characteristic for biologically valuable forests in the Southern Taiga (Andersson et al., 2009) and is included in the Red Data Books of Karelia (2007) and Murmansk region (Konoreva, 2014).

Amandinea punctata (Hoffm.) Coppins et Scheid - on bark of Salix sp. and Abies sibirica; collecting sites: 1, coll. Davydov 10154, Davydov 10505, 10541, Konoreva.

!Arthonia apatetica (A. Massal.) Th. Fr. - on bark of Salix sp., collecting site: 2, coll. Davydov 10745 .

NotE: Arthonia apatetica is an inconspicuous boreal species with a scattered distribution in Europe and North America (Smith et al., 2009). It is characterized by a granular, green thallus, convex, blackish apothecia, and 1-septate ascospores. It can be distinguished from the closely related species $A$. muscigena and $A$. patellulata by the structure of its paraphyses.

Arthonia radiata (Pers.) Ach. - on bark of Abies sibirica, Populus tremula and Sorbus sibirica; collecting sites: 1, 2, coll. Davydov 10737, Davydov 10514, 10545, Konoreva.

Arthonia ruana A. Massal. - on bark of Sorbus sibirica, collecting site: 1, coll. Davydov 10205.
Alyxoria varia (Pers.) Ertz et Tehler - on bark of Populus tremula; collecting sites: 1, 2; coll. Davydov 10185, Davydov 10564, Konoreva.

Athallia pyracea (Ach.) Arup, Frödén et Søchting (syn. Caloplaca pyracea (Ach.) Th. Fr.) on bark of Populus tremula; collecting site: 2, coll. Davydov10552, Konoreva.

!Bacidia circumspecta (Norrl. et Nyl.) Malme on bark of Populus tremula; collecting site: 2, coll. Davydov 11288, Konoreva.

Russian Distribution: Karelia and Komi Republics, Leningrad, Ulyanovsk regions (Golubkova, 2003), Caucasus (Urbanavichus, 2010), Omsk region(Golubkova, 2003), Novosibirsk region (Sedelnikova, 2007), Primorskiy krai (Galanina, Yakovchenko, 2007), Amur region (Golubkova, 2003).

Note: It is morphologically similar to $B$. ignarii, but differs in having 3-6 septate ascospores.

Bacidia fraxinea Lönnr. - on bark of Populus tremula; collecting site: 1, coll. Davydov 10597, 10598, Konoreva.

!Bacidia igniarii (Nyl.) Oxner - on bark of Abies sibirica; collecting site: 1, coll. Davydov 10181.

!Bacidia incompta (Borr.) Anzi - on bark of Abies sibirica; collecting site: 2, coll. Davydov 10165.

NotE: This rare circumboreal species is characterized by having a thin, granular to verrucose thallus, black apothecia, with a thin margin, bacilliform to acicular ascospores and dark-brown hypothecium.

!Bacidia polychroa (Th. Fr.) Körb. - on bark of Populus tremula; collecting site: 1, coll. Davydov 11290.

!Bacidia subincompta (Nyl.) Arnold - on bark of Sorbus sibirica and Caragana arborescens; collecting site: 2, coll. Davydov 10203, Davydov 11289 , Konoreva.

NotE: A common species in old woodlands as well as secondary forests in many countries, occasionally occuring in open habitats from Arctic to the steppe zone. The species was recorded for Novosibirsk region (Sedelnikova, 2007), but probably overlooked in Altaisky krai.

!!Bacidina delicata (Larbal. ex Leight.) V. Wirth et Vězda - on bark of Populus tremula and Abies 
sibirica; collecting sites: 2, coll. Davydov 10593, Konoreva.

RUSSIAN DISTRIBUTION: Belgorod region (Konoreva, Muchnik, 2005), European part of Russia (Muchnik, 2005; Notov et al., 2011), Caucasus (Ismailov, Urbanavichus, 2013), and East Siberia (Urbanavichene, Urbanavichus, 2009).

Note: Not rare, but an often overlooked, boreal species, with a wide-spreading, pale green leprose thallus and small, pale-pink apothecia with thinly needle-shaped, 3-7 septate ascospores. This is a new record for West Siberia.

Biatora chrysantha (Zahlbr.) Printzen - on bark of Abies sibirica; collecting sites: 1, 2, coll. Davydov 11252, 11254.

TLC: gyrophoric acid.

!Biatora efflorescens (Hedl.) Räsänen - on bark of Populus tremula; collecting site: 1, coll. Davydov 11219.

TLC: argopsin.

Note: Not rare, though usually occurring in a sterile form. The species is similar to $B$. chrysantha. The latter, however, differs from $B$. efflorescens in having a yellowish thallus containing gyrophoric acid (Printzen, 1995).

Bryoria capillaris (Ach.) Brodo et D. Hawkskw.on bark of trunks and branches of Abies sibirica; collecting site: 3, coll. Davydov 10144.

Bryoria nadvornikiana (Gyeln.) Brodo et D. Hawkskw. - on bark and branches of Abies sibirica; collecting site: 1, coll. Davydov 10156.

Buellia disciformis (Fr.) Mudd - on bark of Sorbus sibirica; collecting site: 1, coll. Davydov 10024.

Buellia schaereri De Not. - on bark of Abies sibirica; collecting sites: 1 3, coll. Davydov 10126, 10155.

!Calicium denigratum (Vein.) Tibell - on wood of stump; collecting site: 1, coll. Davydov 10500, Konoreva.

Note: This is not rare, but is an often overlooked species with a scattered distribution throughout the boreal zone. It is characterized by having $0.7-1.3$ $\mathrm{mm}$ tall, shiny black ascomata, the absence of pruina, and having a bell-shaped capitulum.

At sites where the species has been collected in Europe, Siberia and North America, it occurs in open canopy woodlands on the Plains and in forest belt of Mountains (McMullin et al., 2012).

Calicium salicinum Pers. - on wood; collecting site: 3, coll. Davydov 10188.

Calicium trabinellum Ach. - on stump; collecting site: 2, coll. Davydov 10534, Konoreva.

Calicium viride Pers. - on bark of Abies sibirica; collecting sites: 1, 2, coll. Davydov 10192, Davydov 10583, Konoreva.

Caloplaca cerina (Ehrh.) Th. Fr. - on bark of Populus tremula, collecting site: 1, 2, coll. Davydov 10095, Davydov 10551, Konoreva.

Caloplaca pyracea (Ach.) Th. Fr. - on bark of Populus tremula, collecting site: 2, coll. Davydov 10552, Konoreva.

Catillaria nigroclavata (Nyl.) Schul. - on bark of Betula pendula; collecting site: 4, coll. Davydov 10563, Konoreva.

Chaenotheca chrysocephala (Turn.) Th. Fr. on bark of Abies sibirica; collecting site: 1, 3, coll. Davydov 10127, 10795.

Chaenotheca furfuracea (L.) Tibell - on bark of Abies sibirica, stump of Betula sp. and tree roots, collecting site: 2, coll. Davydov 10183, 10196, Davydov 10531, Konoreva.

Chaenotheca stemonea (Ach.) Müll. Arg. - on bark of old Abies sibirica; collecting site: 3, coll. Davydov 10197.

Chaenotheca trichialis (Ach.) Th. Fr. - on bark of Abies sibirica and Picea obovata; collecting sites: 1, 2, coll. Davydov 10195, 10270, 10796, Davydov 10542, Konoreva.

Cladonia cenotea (Ach.) Schaer. - on the base of a trunk, on log, on wood of stump; collecting site: 2, coll. Davydov 10513, Davydov 10509, 10526, Konoreva.

Cladonia chlorophaea (Flörke) Spreng. s. 1. - on bark of Picea obovata and wood, collecting site: 1, coll. Davydov 10508, 10543, 10558, Konoreva.

Cladonia coniocraea (Flörke) Spreng. - on bark of Abies sibirica, Picea obovata on stump, dry tree, 
log, wood; collecting site: 2 , coll. Davydov 10507 $10511,10512,10529,10539,10559,10566,10600$, Konoreva.

Cladonia fimbriata (L.) Fr. - on dry tree, stump, log; collecting sites: 2, coll. Davydov 10537, 10538, 10567, Konoreva.

Collema furfuraceum (Arnold) $\mathrm{Du}$ Rietz em. Degel. - on bark of Populus tremula; collecting site: 1, coll. Davydov 10104, 10115.

Evernia divaricata (L.) Ach. - on bark and branches of Abies sibirica; collecting sites: 1, 3, coll. Davydov 10124, 10140, 10157, 10186.

Evernia mesomorpha Nyl. - on bark of dry Abies sibirica, Salix sp.; collecting site: 1, 3, coll. Davydov 10150, 10178.

!!Fuscidea pusilla Tønsberg - on dry tree; collecting site: 2, coll. Davydov 10603, Konoreva.

RUSSIAN DISTRIBUTION: Leningrad region, Karelia, Ural Mts., and West Siberia (Makarova, 2004; Muchnik et al., 2009; Urbanavichus, 2010; Paukov, Teptina, 2013). This is a new record for South Siberia.

TLC: divaricatic acid.

Note: This species is characterized by having small dark-green circular thalli with a blackish hypothallus, initially well-separated soralia, later coalescing and the presence of divaricatic acid.

Gyalolechia ussuriensis (Oxner et al.) Vondrák (Syn. Caloplaca ussuriensis Oxner et al.) - on bark of Populus tremula, collecting site: 1, coll. Davydov 11220.

RUSSIAN DISTRIBUTION: The species was previously reported from the area by Vondrák et al. (2016). Additionally, the species was recorded from Sayan Mountains and Far East - Sikhote-Alin Ridge and Kamchatka (ibid).

Note: The species is characterized by having a thick, distinctly cracked thallus with yellow soralia, apothecia $0.5-1 \mathrm{~mm}$ diam. with brown to dark brown disc and broadly ellipsoid to almost spherical ascospores. This species is closely related to Caloplaca oxneri has been recently described from Russian Far East (Kondratyuk et al., 2011) and is associated with humid taiga forests from Siberia and the Far East.

Hypogymnia physodes (L.) Nyl. - on bark and branches of Abies sibirica; collecting site: 1,2; coll.
Davydov 10158, 10572, 10180; Davydov 10595, Konoreva.

Hypogymnia tubulosa (Schaer.) Hav. - on branches of Abies sibirica; collecting site: 1, coll. Davydov 10574, Konoreva.

Japewia tornoënsis (Nyl.) Tønsberg - on branches of Abies sibirica; collecting site: 2, coll. Davydov 10143.

Lecania cyrtella (Ach.) Th. Fr. - on bark of Salix sp.; collecting site: 2, coll. Davydov 10744.

Lecanora allophana Nyl. - on bark of Populus tremula; collecting site: 1, coll. Davydov 10201; 10114; 10145.

Lecanora argentata (Ach.) Malme - on bark of Populus tremula, on log (Abies sibirica); collecting sites: 1, 2, coll. Davydov 10521, 10527, 10592, Konoreva.

Lecanora chlarotera Nyl. - on bark of Abies sibirica, on dry branches; collecting sites: 1, coll. Davydov 10162; Davydov 10565, Konoreva.

Lecanora symmicta (Ach.) Ach. - on bark of Salix sp., on bark and branches of Abies sibirica; collecting sites: 1, 2, coll. Davydov 10153; Davydov 11262; Davydov 10515, Konoreva; Davydov 10141, Davydov 10166.

Lecidella elaeochroma (Ach.) Choisy - on bark and branches of Abies sibirica, on bark of Sorbus sibirica; collecting site: 1, coll. Davydov 10161, Davydov 10561, Davydov 10580, Konoreva.

Lecidella euphorea (Flörke) Hertel - on bark of Populus tremula, on branches of Abies sibirica; collecting site: 1, coll. Davydov 10113; Davydov 10202; Davydov 10518, Konoreva.

Leptogium saturninum (Dicks.) Nyl. - on bark of dry Abies sibirica; collecting site: 1, coll. Davydov 10532, Konoreva.

Lobaria pulmonaria (L.) Hoffm. - on bark of Betula pendula, Salix sp., dry tree; collecting site: 1, coll. Davydov 10110; Davydov 10123; Davydov 10519, Konoreva.

The species has been previously reported from the area by Davydov (1999). Lobaria pulmonaria is 
included in the Red Data Book of Russia (Istomina, 2008).

Megaspora verrucosa (Ach.) Hafellner et V. Wirth - on bark of Populus tremula, collecting site: 1, coll. Davydov 10785.

Melanohalea septentrionalis (Lynge) O. Blanco et al. - on bark of Salix sp., collecting site: 1, coll. Davydov 10152.

!Melanelixia fuliginosa (Fr. ex Duby) Essl. subsp. glabratula Lamy - on bark of Sorbus sibirica; collecting site: 1, coll. Davydov 10112.

Melanelixia subaurifera (Nyl.) O. Blanco et al. - on branches of Abies sibirica; collecting site: 1, coll. Davydov 10516, Konoreva.

!Micarea lignaria (Ach.) Hedl. - on wood; collecting site: 1, coll. Davydov 10122.

Micarea prasina s. 1. - on bark of Abies sibirica; collecting site: 2, coll. Davydov 10125.

Mycobilimbia carneoalbida (Müll. Arg.) S. Ekman et Printzen - at the base of a trunk of Populus tremula; collecting site: 1, coll. Davydov 10173.

The species has been previously reported from the area by Davydov (2004).

!Mycobilimbia epixanthoides (Nyl.) Vitik. et al. - at the base of a trunk of Populus tremula; collecting sites: 1, coll. Davydov 10174.

Mycobilimbia tetramera (De Not.) Vitik. et al. at the base of a trunk of Populus tremula, collecting site: 1, coll. Davydov 10172.

Ochrolechia pallescens (L.) A. Massal. - on bark of Sorbus sibirica, collecting site: 1, coll. Davydov 10167.

Parmelia sulcata Taylor - on bark and branches of Abies sibirica, on bark of Populus tremula, Sorbus sibirica, Salix sp. on stump; collecting sites: 1, 2, coll. Davydov 10194, 10146, 10151, 10169 , 10111, 10179; Davydov 10525, 10560, 10573; 10594, Konoreva.

Parmeliopsis ambigua (Wulfen) Nyl. - on bark of Abies sibirica; collecting site: 1, coll. Davydov 10506, Konoreva.
Peltigera didactyla (With.) J. R. Laundon - on mosses over log; collecting site: 1, coll. Davydov 10535, Konoreva.

Peltigera polydactylon (Neck.) Hoffm. - on log (Abies sibirica), wood of stump; collecting sites: 1, 2, coll. Davydov 10107; Davydov 10510, 10520, 10540, 10503, Konoreva.

Peltigera praetextata (Flörke) Vain. - on log; collecting sites: 1, coll. Davydov 10130, Davydov 10536, Konoreva.

Pertusaria albescens (Huds.) M. Choisy et Werner - on bark of Sorbus sibirica; collecting site: 1, 2, coll. Davydov 10168; Davydov 10171.

Pertusaria amara (Ach.) Nyl. - on bark and branches of Abies sibirica; collecting site: 1, coll. Davydov 10159, 10164; Davydov 10568, Konoreva.

!Pertusaria hemisphaerica (Flörke) Erichsen on wood; collecting site: 1, coll. Davydov 11255.

TLC: lecanoric acid.

!Pertusaria leioplaca DC. - on bark of Sorbus sibirica; collecting site: 1, coll. Davydov 10007.

Note: A circumboreal species closely related to P. alpina Hepp but differs in its 4-spored asci.

+!!Phaeocalicium polyporaeum (Nyl.) Tibell on Polypore fungi; collecting site: 2, coll. Davydov 10105, Konoreva.

RUSSIAN DISTRIBUTION: A boreal species with a scattered distribution; common in humid lowland forests in Caucasus, Far East of Asia, and in North America, relatively rare in Europe, recorded in Romania (locus classicus) and the north of European Russia (Titov, 2006). This is a new record for Siberia.

Note: The species is characterized by having 2-celulled hyaline ascospores and its specialised substrate - polypore fungi.

Phaeophyscia ciliata (Hoffm.) Moberg - on bark of Populus tremula; collecting site: 1, coll. Davydov 10554, Konoreva.

Phaeophyscia hispidula (Ach.) Essl. - on bark of Populus tremula; collecting site: 1, Davydov 10149.

Phaeophyscia nigricans (Flörke) Moberg - on bark of Populus tremula; collecting site: 1, coll. Davydov 10118. 
Phaeophyscia orbicularis (Necker) Moberg on bark of Populus tremula; collecting site: 1, coll. Davydov 10148.

Phlyctis argena (Spreng.) Flot. - on bark of Populus tremula, Picea obovata, Sorbus sibirica, Salix sp., on branches of Abies sibirica; collecting sites: 1, 2, coll. Davydov 10147, 10170, 10189, 10528; Davydov 10569, Konoreva.

Physcia aipolia (Ehrh. ex Humb.) Furnr. - on bark of Populus tremula, collecting sites: 1, coll. Davydov 10116; Davydov 10553, Konoreva.

Physconia distorta (With.) J. R. Laundon. - on bark of Populus tremula; collecting sites: 1, coll. Davydov 10117; Davydov 10501, Konoreva.

Physconia enteroxantha (Nyl.) Poelt - on bark of Abies sibirica, collecting site: 1, coll. Davydov 10533

!Placynthiella dasaea (Stirt.) Tønsberg - on wood; collecting site: 1, coll. Davydov 10602, Konoreva.

Note: A widespread, boreal, usually sterile species differing from Placynthiella icmalea (Ach.) Coppins et P. James by the globose soredia.

!Pseudoschismatomma rufescens (Pers.) Ertz et Tehler - on bark of Abies sibirica; collecting site: 1, coll. Davydov 10163.

Ramalina farinacea (L.) Ach. - on bark of Populus tremula, Sorbus sibirica, Salix sp., on branches of Picea obovata; collecting site: 1, 2, coll. Davydov, 10106, 10108, 10137, 10190, 10199.

Ramalina obtusata (Ach.) Bitt. - on bark and branches of Abies sibirica, on bark of Betula pendula; collecting sites: 1, 2, coll. Davydov 10139, 10160, 10182, 10198

Ramalina roesleri (Hochst.) Nyl. - on bark of Populus tremula, Sorbus sibirica; collecting sites: 1, 2, coll. Davydov 10109, 10200; Davydov 10524, Konoreva.

Note: the species is included in the Red Data Book of Altaisky krai (Davydov, 2016).

Ramalina thrausta (Ach.) Nyl. - on branches of Abies sibirica, collecting site: 2, coll. Davydov 10138.
!Rinodina efflorescens Malme - on bark of Betula pendula; collecting sites: 1, coll. Davydov 11283.

TLC: pannarin.

Note: The species is similar to $R$. griseosoralifera Coppins but differs from it by Pachyospora-type ascospores, blue-tinted soralia and having pannarin as a secondary metabolite. Probably widespread, but often overlooked.

Rinodina septentrionalis Malme - on bark of Abies sibirica, collecting site: 1, coll. Davydov 10193.

Schizoxylon albescens Gilenstam et al. - on dry branch of Populus tremula; collecting site: 1, Davydov 10601, Konoreva.

RUSSIAN DISTRIBUTION: The species was previously reported from the area by Konoreva et al. (2016). Additionally, the species was recorded from Altai Mountains and East Siberia - Stanovoye Upland and Yakutia (ibid.).

Scoliciosporum chlorococcum (Graewe ex Stenham.) Vězda - on bark of Abies sibirica; collecting site: 1, Davydov 10191.

Tetramelas insignis (Nägeli ex Hepp) Kalb on bark of Sorbus sibirica; collecting site: 2, coll. Davydov 10204.

Trapeliopsis flexuosa (Fr.) Coppins et P. James on bark of Abies sibirica; collecting site: 1, coll. Davydov 10596, Konoreva.

Usnea dasypoga (Ach.) Nyl. - on Abies sibirica trunk and branches; collecting site: 1, 2, coll. Davydov s. n.

Usnea fulvoreagens (Räsänen) Räsänen - on Abies sibirica trunk and branches; collecting site: 1 , 2, coll. Davydov s. n.

Usnea subfloridana Stirt. - on Abies sibirica trunk and branches; collecting site: 1, 2, coll. Davydov s. n.

Vulpicida pinastri (Scop.) J.-E. Mattson et M. J. Lai - on stump; collecting site: 1, coll. Davydov 10530, Konoreva.

!Xanthomendoza fulva (Hoffm.) Søchting et al. - on bark of Populus tremula; collecting site: 1, Davydov 10119. 
RUSSIAN Distribution: North-West of European part (Leningrad Region (Kuznetzova et al., 2007), Russian Plain (Konoreva et al., 2006; Notov et al., 2011), Caucasus (Ismailov, Urbanavichus, 2013), South Ural (Urbanavichus, Urbanavichene, 2010), and Siberia - Tuva (Sedelnikova, 2013).

Nоте: The species is characterized by having small thalli with mainly vertical, distinctly dorsiventral lobes, blastidiose at their lower surface margins.

\section{Acknowledgements}

The authors are grateful to J. V. Gerasimova for revision of our collection of genera Bacidia and Bacidina, Dr. I. A. Galanina for the confirmation of our identification of lichens from the genus Rinodina, to A. V. Gribkov for organizing an expedition in the Zalesovsky zakaznik and to Dr. William Purvis for improving the text.

\section{REFERENCES / ЛИTEPATУPA}

Andersson L., Alexeeva N. M., Kuznetsova E. S. (eds.) 2009. Survey of biologically valuable forests in NorthWest of European Russia. 2. Identification manual of species to be used during survey at stand level. Printing house «Pobeda», St. Petersburg, 258 pp. [In Russian]. (Андерсен Л., Алексеева Н. М., Кузнецова Е. С. (ред.) Выявление и обследование биологически ценных лесов на Северо-Западе Европейской части России. Т. 2. Пособие по определению видов, используемых при обследовании на уровне выделов. СПб.: изд. дом «Победа», 2009. 258 c.).

Baumgertner M. V. 2012. Lichen-indication of Salair Ridge in the limits of the territory of Kemerovo Region. Problemy Regionalnoy Ekologii [Problems of regional ecology] 1: 90-92 [In Russian]. (Баумгертнер М. В. Лихеноиндикация Салаирского кряжа в пределах территории Кемеровской области // Проблемы региональной экологии, 2012, № 1. С. 90-92).

Culberson C. F., Kristinsson H. A. 1970. A standardized method for the identification of lichen product. Journal of Chromatography 46, 2: 85-93.

Davydov E. A. 1999. Lichen from Red data book of USSR and Russia, Lobaria pulmonaria (L.) Hoffm. (Lobariaceae, Lichenes), in Altai region. Flora and vegetation of Altai 4, 1: 18-23 [In Russian]. (Давыдов Е. А. Лишайник из Красных книг СССР и РСФСР Lobaria pulmonaria (L.) Hoffm. (Lobariaceae, Lichenes) в Алтайском крае // Флора и растительность Алтая. Барнаул, 1999. Т. 4, вып. 1. С. 18-23).

Davydov E. A. 2001. Annotated list of lichens of Western part of Altai (Russia). Novosti sistematiki nizshikh rasteniy [Novit. Syst. Pl. non Vasc.] 35: 140-161 [In Russian]. (Давыдов E. A. Аннотированный список лишайников западной части Алтая (Россия) // Нов. сист. низш. раст. 2001, Т. 35. С. 140-161).

Davydov E. A. 2004. Additions to Lichen biota of Altai Mounts (Siberia). I. Turczaninowia 7, 4: 47-59 [In Russian]. (Давыдов Е. А. Дополнения к видовому составу лишайников Алтайской горной страны. I. Turczaninowia, 2004. Т. 7, вып. 4. С. 47-59).

Davydov E. A. 2014. The first checklist of lichens, lichenicolous, and allied fungi of Altai Territory (Siberia, Russia). Mycotaxon 127: 1-67. http://www.mycotaxon.com/resources/checklists/davydov-v127-checklist.pdf

Davydov E. A. 2016. Ramalina roesleri (Schaer.) Hue. In: Red Data Book of Altaiskiy krai. Rare and vulnerable species of Plants and Fungi. Izd-vo AGU, Barnaul, 230 p. [In Russian]. (Давыфов E. A. Рамалина Рослера - Ramalina roesleri (Schaer.) Нue. // Красная книга Алтайского края. Т. 1. Редкие и находящиеся под угрозой исчезновения виды растений и грибов. Барнаул: Изд-во Алт. ун-та, 2016. С. 230).

Davydov E. A., Konoreva L. A., Andreev M. P., Zhdanov I. S., Dobrysh A. A. 2012. Additions to the lichen biota of Altai Mountains. IV. Turczaninowia 15, 3: 23-36.

Davydov E. A., Printzen Ch. 2012a. Additions to the lichen biota of the Altai Mountains (Siberia). III. Turczaninowia 15, 1: 85-91.

Davydov E. A., Printzen Ch. 2012b. Rare and noteworthy boreal lichens from the Altai Mountains (South Siberia, Russia). Bryologist 115, 1: 61-73. DOI: 10.1639/0007-2745.115.1.61

Davydov E. A., Skachko E. Yu. 2014. History and results of Altai Territory lichen flora investigation. Vestnik Altaiskoy nauki 1: 208-213 [In Russian]. (Давыдов Е. А., Скачко Е. Ю. История и итоги изучения флоры лишайников Алтайского края // Вестник алтайской науки, 2014. № 1. С. 208-213).

Davydov E. A., Titov A. N., Zamora S. P. 2007. Additions to Lichen biota of Altai Mounts (Siberia). II. Turczaninowia 10, 1: 60-67 [In Russian]. (Давыdов Е. А., Титов А. Н., Замора С. П. Дополнения к видовому составу лишайников Алтайской горной страны. II. // Turczaninowia, 2007. T. 10, № 1. С. 60-67).

Fadeeva M. A. 2005. Nemoral species of lichen flora in Karelia. Biogeography of Karelia. In: Proceedings of the Karelian Research Centre RAS. Iss. 7. Petrozavodsk, 255-265 pp. [In Russian]. (Фадеева М. А. Неморальные виды во флоре лишайников Карелии / Биогеография Карелии // Труды Карельского научного центра РАН. Вып. 7. Петрозаводск, 2005. С. 255-265). 
Fadeeva M. A. 2008. Red Data Book of Karelia Republic: comments to the checklist of lichens. In: Fundamental and Applied Botany at the beginning of the XXI century: Proceedings of the All-Russian Conference. 2. Algology, Mycology, Bryology and Lichenology. Eds. K. L. Vinogradova et al. Karelia Science Center RAS, Petrozavodsk, 255-258 pp. [In Russian]. (Фадеева M. A. Красная книга Карелии: комментарии к списку лишайников // Фундаментальные и прикладные проблемы ботаники в начале XXI века: Материалы всерос. конф. Ч. 2: Альгология. Микология. Лихенология. Бриология. Петрозаводск: Карельский научный центр РАН, 2008. С. 255-258).

Galanina I. A., Yakovchenko L. S. 2007. Epiphytic lichens on dentate oak (Quercus dentata) in Primorie Territory. Novosti sistematiki nizshikh rasteniy [Novit. Syst. Pl. non Vasc.] 41: 180-192 [In Russian]. (Галанина И. А., Яковченко Л. С. Эпифитные лишайники дуба зубчатого (Quercus dentata) в Приморском крае // Нов. сист. низш. раст. 2007, T. 41. С. 180-192).

Golubkova N. S. 2003. Genus Bacidia. In: Handbook of the lichens of Russia. Iss. 8. Bacideaceae, Catillariaceae, Lecanoraceae, Megalariaceae, Mycobilimbiaceae, Rhizocarpaceae, Trapeliaceae. Nauka, St. Petersburg, 12-39 pp. [In Russian]. (Голубкова H. C. Род Bacidia. Определитель лишайников России. Вып. 8. Бацидиевые, Катилляриевые, Леканоровые, Мегалариевые, Микобилимбиевые, Ризокарповые, Трапелиевые. СПб.: Наука, 2003. С. 12-39).

Hermansson Ya.-O., Pystina T. N., Ove-Larsson B., Zhurbenko M. P. 2006. Lichens and Lichenicolous Fungi of the Pechoro-Ilychski Nature Reserve. Flora and Fauna of Nature Reserves 109: 79 pp. [In Russian]. (Херманссон Я.-О., Пыстина Т. Н., Ове-Ларссон Б., Журбенко М. П. Лишайники и лихенофильные грибы Печеро-Илычского заповедника // Флора и фауна заповедников, 2006. Вып. 109. 79 с.).

Himelbrant D., Stepanchikova I., Motiejūnaitè J., Vondrak J., Tagirdzhanova G., Gagarina L., Kuznetsova E. 2015. New records of lichens and allied fungi from the Leningrad Region, Russia. VI. Folia Cryptogamica Estonica 52: $21-28$.

Ismailov A. B., Urbanavichus G. P. 2013. Epiphytic lichens of Gunib Plateau (the intramontane Dagestan). Proceedings of the Samara Scientific Center of the Russian Academy of Sciences 15, 3: 69-77 [In Russian]. (Иcмauлов А. Б., Урбанавичюс Г. П. Эпифитные лишайники Гунибского плато (внутригорный Дагестан) // Известия Самарского научного центра Российской академии наук, 2013. Т. 15, № 3. С. 69-77).

Istomina N. B. 2008. Lobaria pulmonaria (L.) Hoffm. In: Red Data Book of Russia (plants and mushrooms). KMK, Moscow, 715-716 pp. [In Russian]. (Истомина Н. Б. Lobaria pulmonaria (L.) Hoffm. // Красная книга Российской Федерации (растения и грибы). М.: Товарищество научных изданий КМК, 2008. С. 715-716).

Ivanter E. V., Kuznetsov O. L. (eds.) 2007. Red Data Book of Karelia Republic. Karelia, Petrosavodsk, 368 pp. [In Russian]. (Красная книга Республики Карелия / Э. В. Ивантер, О. Л. Кузнецов (науч. ред). Петрозаводск: Карелия, 2007. 368 с.).

Konoreva L. A. 2014. Acrocordia cavata (Ach.) R. C. Harris. In: Red Data Book of Murmansk Region. Eds. N. A. Konstantinova et al. Asia-print, Kemerovo. 119 p. [In Russian]. (Конорева Л. А. Акрокордия каверновая - Acrocordia cavata (Ach.) R. C. Harris. // Красная книга Мурманской области. Изд. 2-е, перераб. и доп. Н. А. Константинова и др. (ред). Кемерово: «Азия-принт», 2014. С. 119).

Konoreva L. A., Chesnokov S. V., Davydov E. A. 2016. Stictis and Schizoxylon (Stictidaceae, Ostropales) in Russia. Herzogia 29, 2: 706-711. DOI: 10.13158/heia.29.2.2016.706

Konoreva L. A., Muchnik E. E. 2013. Lichens of Aydarsky territory Rovensky Natural Park and the surroundings (Belgorod region). In: Flora and vegetation of the Central Chernozem region - 2013. Eds. O. V. Ryzkov et al. Publishing house «Mechta», Kursk, 215-220 pp. [In Russian]. (Конорева Л. А., Мучник Е. Э. Лишайники участка Айдарский природного парка Ровеньский и его окрестностей (Белгородская область) // Флора и растительность Центрального Черноземья - 2013. Курск, 2013. С. 215-220).

Konoreva L. A., Muchnik E. E. 2005. To study of lichens of Belgorod region. Novosti sistematiki nizshikh rasteniy [Novit. Syst. Pl. non Vasc.] 38: 200-212 [In Russian]. (Конорева Л. А., Мучник Е. Э. К изучению лишайников Белгородской области // Нов. сист. низш. раст. 2005, Т. 38. С. 200-212).

Konoreva L. A., Muchnik E. E., Urbanavichene I. N., Urbanavichus G. P. 2006. Proposal to include of lichens in the Red Data Book of the Kursk region. In: Studies on the Red Data Book of the Kursk region. Kursk State University, Kursk, 110-128 pp. [In Russian]. (Конорева Л. А., Мучник Е. Э., Урбанавичене И. Н., Урбанавичюс Г. П. Предложения по включению лишайников в Красную книгу Курской области // Исследования по Красной книге Курской области, 2006. С. 110-128).

Korchikov E. S. 2006. Lichens of Samara region. Bulletin of the Samara State University. The natural science series 7(47): 95-107 [In Russian]. (Корчиков E. C. Лишайники Самарской области // Вестник СамГУ. Естественнонаучная серия, 2006. № 7(47). С. 95-107).

Kovaleva N. M. 2006. Addition to the lichen flora of marshes and swampy forests of Tomsk Region. Novosti sistematiki nizshikh rasteniy [Novit. Syst. Pl. non Vasc.] 40: 230-234 [In Russian]. (Ковалева Н. М. Дополнение к лихенофлоре болот и заболоченных лесов Томской области // Нов. сист. низш. раст., 2006. Т. 40. С. 230-234).

Kuznetsova E., Ahti T., Himelbrant D. 2007. Lichens and allied fungi of the Eastern Leningrad Region. Norrlinia 16: 1-62. 
Makarova I. I. 2004. Family Fuscideaceae. In: Handbook of the lichens of Russia. Iss. 9. Fuscideaceae, Teloschistaceae. St. Petersburg, 10-36 pp. [In Russian]. (Макарова И. И. Семейство Fuscideaceae // Определитель лишайников России. Вып. 9. Фусцидеевые, Телосхистовые. СПб.: Наука, 2004. С. 10-36).

McMullin, R. T., Selva S. B., Maloles J. R., Newmaster S. G. 2012. Calicium denigratum (Vain.) Tibell, a new lichen record for North America. North American Fungi 7, 11: 1-5. DOI: http://dx.doi: 10.2509/naf2012.007.011

Melekhin A. V. 2013. Addition to the lichen biota of Murmansk region. Herald of the Kola Science Centre RAS 4, 15: 105-107 [In Russian]. (Мелехин A. В. Дополнения к лихенобиоте Мурманской области // Вестник Кольского научного центра РАН, 2013. Т. 4, вып. 15. С. 105-107).

Muchnik E. E., Konoreva L. A., Dobrysh A. A., Makarova I. I., Titov A. N. 2009. Checklist of lichens Darvin State Biosphere Reserve (Vologda and Yaroslavl regions, Russia). Bulletin of Tver State University Iss. "Biology and Ecology” 14: 174-194 [In Russian]. (Мучник Е. Э., Конорева Л. А., Добрыш А. А., Макарова И. И., Титов $\boldsymbol{A}$. $\boldsymbol{H}$. Конспект лишайников Дарвинского государственного природного биосферного заповедника (Вологодская и Ярославская область, Россия) // Вестник ТвГУ. Серия «Биология и экология». Вып. 14, 2009. С. 174-194).

Notov A. A., Himelbrant D. E., Urbanavichus G. P. 2011. Annotated list of the lichen flora of the Tver region. Tver State University, Tver, 124 pp. [In Russian]. (Нотов А. А., Гимельбрант Д. Е., Урбанавичюс Г. П. Аннотированный список лихенофлоры Тверской области. Тверь: Твер. гос. ун-т, 2011. 124 с.).

Otte $\boldsymbol{V}$. 2005. Notes on the lichen flora of the Black Sea coast of Russia. Novosti sistematiki nizshikh rasteniy [Novit. Syst. Pl. non Vasc.] 39: 248-253 [In Russian]. (Omme Ф. Заметки о лихенофлоре Российского побережья Черного моря // Нов. сист. низш. раст., 2005. Т. 39. С. 248-253).

Paukov A. G., Teptina A. Yu. 2013. Lichens of "Olenyi Ruchyi” Nature Park (Sverdlovsk Region). Novosti sistematiki nizshikh rasteniy [Novit. Syst. Pl. non Vasc.] 47: 237-252 [In Russian]. (Пауков А. Г., Тептина А. Ю. Лишайники природного парка «Оленьи ручьи» (Свердловская область) // Нов. сист. низш. раст., 2013. Т. 47. C. 237-252).

Printzen C. 1995. Die Flechtengattung Biatora in Europa. In: Bibliotheca Lichenologica, 60. J. Cramer, Berlin, Stuttgart, $275 \mathrm{pp}$.

Sedelnikova N. V. 2007. Lichens. In: Flora Salairskogo kriazha [Flora of Salair Ridge]. Ed. N. N. Lashchinsky. Geo, Novosibirsk, 98-136 pp. [In Russian]. (Седельникова Н. В. Лишайники // Флора Салаирского кряжа. Новосибирск: Гео, 2007. С. 98-136).

Sedelnikova N. $\boldsymbol{V}$. 2013. Species diversity of lichen biota of the Altai-Sayan ecological region. The flora of Asian Russia 2, 12: 12-54 [In Russian]. (Седельникова Н. В. Видовое разнообразие лихенобиоты Алтае-Саянского экорегиона // Растительный мир Азиатской России, 2013, № 2(12), С. 12-54).

Shmakov A. I., Smirnov S. V., Kechaykin A. A., Andreyeva I. V., Rotanova I. N., Votinov A. G., Irisova N. L., Shvetsov Yu. G. 2009. Zakaznik Zalesovskiy. In: Red Data Book of Altaiskiy krai. Vol. 3. Specially Protected Nature Areas. Barnaul, 58-61 pp. [In Russian]. (Шмаков А. И., Смирнов С. В., Кечайкин А. А., Андреева И. В., Ротанова И. Н., Вотинов А. Г., Ирисова Н. Л., Швецов Ю. Г. Заказник Залесовский // Красная книга Алтайского края. Т. 3. Особо охраняемые природные территории. 2-е издание. Барнаул, 2009. С. 58-61).

Silantieva M. M. 2006. Konspekt flory Altayskogo kraya [The sinopsis of the Altaisky krai flora]. Barnaul, 392 pp.

[In Russian]. (Силантьева М. М. Конспект флоры Алтайского края. Барнаул, 2006. 392 с.).

Smith C. W., Aptroot A., Coppins B. J., Fletcher A., Gilbert O. L., James P. W., Wolseley P. A. (ed.) 2009. The Lichens of Great Britain and Ireland. Great Britain, MPG Books Group, Bodmin and King's Lynn. 1046 pp.

Stas' Ye. Yu. 1999. New record of Ramalina sinensis (Ramalinaceae, Lichenes) for the Altai Territory. Turczaninovia 2, 1: 43-44 [In Russian]. (Стась Е. Ю. Находка Ramalina sinensis (Ramalinaceae, Lichenes) в Алтайском крае// Turczaninowia, 1999, Т. 2, вып. 1, C. 43-44).

Stepanchikova I. S., Kuznetsova E. S., Himelbrant D. E. 2009. New records of lichens and allied fungi from the Eastern Leningrad Region. Folia Cryptogamica Estonica 46: 75-78.

Tagirdzhanova G. M., Kataeva O. A., Stepanchikova I. S. 2014. New lichen records from the Novgorod Region, Russia. Folia Cryptogamica Estonica 51: 103-107.

Titov A. N. 2006. Mycocalicioid fungi (the Order Mycocaliciales) of the Holarctic. KMK, Moscow, 296 pp. [In Russian]. (Титов A. Н. Микокалициевые грибы (порядок Mycocaliciales) Голарктики. М.: Товарищество научных изданий КМК, 2006. 296 с.).

Urbanavichene I. N., Urbanavichus G. P. 2009. Addition to the lichen flora of Okinskoye Plateau (Eastern Sayan, Buryatia). Novosti sistematiki nizshikh rasteniy [Novit. Syst. Pl. non Vasc.] 43: 229-260 [In Russian]. (Урбанавичене И. Н., Урбанавичюс Г. П. К флоре лишайников Окинского плоскогорья (Восточный Саян, Бурятия) // Нов. сист. низш. раст., 2009. Т. 43. С. 229-260).

Urbanavichus G. P. (comp.) 2010. A checklist of the lichen flora of Russia. Nauka, St. Petersburg, 194 pp. [In Russian]. (Урбанавичюс Г. П. Список лихенофлоры России. СПб.: Наука, 2010. 194 с.).

Urbanavichus G. P., Urbanavichene I. N. 2010. Lichen flora. In: Flora and vegetation of the National Park "Bashkiria" (syntaxonomy, anthropogenic dynamics, ecological zoning). Ed. B. M. Mirkin. Publishing house «Gilem», Ufa, 64-78 pp. [In Russian]. (Урбанавичюс Г. П., Урбанавичене И. Н. Лихенофлора // Флора и растительность 
Национального парка «Башкирия» (синтаксономия, антропогенная динамика, экологическое зонирование) / Под ред. Б. М. Миркина. Уфа: АН РБ, Гилем, 2010. С. 64-78).

Vondrák J., Frolov I., Davydov E. A., Urbanavichene I., Chesnokov S., Zhdanov S., Muchnik E., Konoreva L., Himelbrant D., Tchabanenko S. 2016. The extensive geographical range of several species of Teloschistaceae: Evidence from Russia. Lichenologist 48: 171-189.

Zhdanov I. S., Volosnova L. F. 2012. Materials for the lichen flora of Mescherskaya lowlands (within the Vladimir and Ryazan regions). Novosti sistematiki nizshikh rasteniy [Novit. Syst. Pl. non Vasc.] 46: 145-160 [In Russian]. (Жданов И. С., Волоснова Л. Ф. Материалы к лихенофлоре Мещерской низменности (в пределах Владимирской и Рязанской областей) // Нов. сист. низш. раст., 2012. Т. 46. С. 145-160). 